\title{
Serum levels of soluble CD95 in patients with systemic lupus erythematosus
}

\author{
Magda I. M. El-Mahdy , Fatma A. Mourad* and Wafaa Afify M.H.** \\ Clinical Pathology, Internal Medicine* and Dermatology** Departments \\ Faculty of Medicine for Girls, Al Azhar University
}

\begin{abstract}
:
The present study was carried out on 30 patients with systemic lupus erythematosus (SLE) and ten apparently healthy individuals as a control group.Systemic lupus erythematosus activity index (SLEDAI) was applied to all patients. Anti-double stranded DNA antibodies (Anti-dsDNA Abs.), interleukin-18 (IL-18) and soluble CD95 (Apo-1/Fas) were determined in the sera of all studied subjects. The mean \pm SD SLEDAI in all patients was $15.25 \pm 6.76$. The anti-dsDNA antibodies was positive in all studied patients (mean \pm SD $264.36 \pm 114.85 \mathrm{IU} / \mathrm{ml}$ ). Serum IL-18 showed significant elevation in SLE patients as compared to the control group (Mean \pm SD $246.13 \pm 114.32 \mathrm{I} \mathrm{U} / \mathrm{ml}$ vs. $45.5 \pm 7.32 \mathrm{IU} / \mathrm{ml} ; \mathrm{p}<0.001)$. Serum Soluble CD95 (sCD95)showed significant increase in all SLE patients as compared to the control group (Mean \pm SD $648 \pm 116.96 \mathrm{pg} / \mathrm{ml}$ vs. $270 \pm 50.24 \mathrm{pg} / \mathrm{ml} ; \mathrm{p}<0.001$ ). Serum sCD95 also showed significant rise in SLE patients with moderate activity as compared to those with mild activity (Mean \pm SD $629.16 \pm 72.54 \mathrm{pg} / \mathrm{ml}$ vs. $535 \pm 35.97 \mathrm{pg} / \mathrm{ml} ; \mathrm{p}<0.05$ ). The serum level of sCD95 in SLE cases with severe activity showed significant increase when compared to those with moderate activity ( Mean \pm SD $797.5 \pm 41.66$ $\mathrm{pg} / \mathrm{ml}$ vs. $629.16 \pm 72.54 \mathrm{pg} / \mathrm{ml} ; \mathrm{p}<0.001)$.

Anti-dsDNA antibodies showed significant positive correlation with SLEDAI $(\mathrm{r}=0.772 ; \mathrm{p}<0.01)$. IL-18 also showed a significant positive correlation with the SLEDAI $(\mathrm{r}=0.670 ; \mathrm{p}<0.01)$.

Soluble CD95 showed significant positive correlation with SLDAI $(r=0.865 ; \mathrm{p}<0.01)$, with anti-dsDNA antibodies $(r=0.775 ; p<0.01)$ and with IL-18 $(r=0.722 ; p<0.01)$.

From these results it was concluded that serum sCD95 is increased in patients with systemic lupus erythematosus and it is correlated with anti-dsDNA antibodies, with IL18 and with the disease activity, so it can be useful marker of disease activity for proper management and follow up of SLE patients.
\end{abstract}

\section{Introduction:}

CD95 (Apo-1/Fas) is a member of the nerve growth factor/tumour necrosis factor receptor superfamily. The Fas protein denots the CD95 receptor and is $45 \mathrm{kDa}$ type I membrane protein(1).The membrane Fas is expressed on various normal human tissues(2). The soluble CD95 molecules are produced either through the proteolytic cleavage of membrane bound receptors or as translation products of alternatively spliced mRNA (3).Interaction of CD95( Fas) with its ligand (Fas L) initiates a signal 
transduction cascade leading to programmed cell death(apoptosis) in susceptible cells(4).This is mediated by activation of proteases termed caspases (5).Apoptosis occurs in normal development and continues in many tissues through life, so unwanted cells can be eliminated (6).

IL-18 is a proinflammatory cytokine which promotes inflammation and apoptosis (7). IL-18 is expressed by various cell types,including macrop hages, denderetic cells, adrenal cortical cells, intestinal cells, skin cells and brain cells (8).

Systemic lupus erythematosus is a systemic autoimmune disease which damages multiple organ systems and cause diverse and variable clinical manifestations(9).

Disturbance in apoptosis or in the clearing of apoptotic material might result in increased presentation of auto antigens which could be related to the pathogenesis of SLE (10).

The aim of this study is to evaluate the level of soluble CD95 in patients with systemic lupus and if it reflects the disease activity and if it correlates with other activity indices as anti-dsDNA antibodies and IL-18.

\section{Subjects and methods:}

This study included 30 patients with systemic lupus erythematosus. They were selected from Internal Medicine Department and Dermatology Clinic in Al-Zahraa University Hospital.They were 5 males and 25 females. Their ages ranged from 18-45 years old. Ten apparently healthy individuals were included as a control group ( 3 males and 7 females, aged from 22-42 years old).

All patients fulfilled the American College of Rheumatology (ACR) criteria for classification of SLE ( 11).

\section{The patients were subjected to :}

Full history and clinical examination.-Abdominal sonography

-Estimation of systemic lupus erythematosus disease activity index (SLEDAI)(12).

A SLEDAI of 1-10 denotes mild activity, 11-20 moderate activity and $\geq$ 21 severe disease activity (13).

-Routine laboratory investigations(urine analysis, kidney and liver function tests and complete blood picture).

The patients and control were subjected to the following laboratory tests:

1- Anti double stranded DNA antibodies, using Immunolisa antidsDNA antibody ELISA (IMMCO Diagnostic USA) It is solid phase ELISA for detection and quantitation of Ig $\mathrm{G}$ antibodies to double stranded DNA in human serum (Positive $>60 \mathrm{IU} / \mathrm{ml}$ ).

2- IL-18 : Using human IL-18 ELISA kit(MBL Medical \&Biological laborat ories, Japan).It is based on sandwich ELISA.

3-Serum soluble CD95, using CD95 (Apo-1/Fas) ELISA kit(Diaclone Research,France). It is a solid phase sandwich Enzyme Linked-ImmunoSorbent assay.

\section{Sampling:}

Ten $\mathrm{ml}$ of venous blood were withdrawn from the studied subjects.

One ml was anticoagulated with EDTA for routine complete blood count. Two $\mathrm{ml}$ were anticoagulated with $3.2 \%$ trisodium citrate solution for erythrocyte sedimentation rate.

The remaining blood were left to clot and serum was separated and divided into 2 aliquots, one for routine liver and kidney function tests. The second aliquot was stored at - $20 \mathrm{C}$ till time of assay of anti- dsDNA, IL-18 and sCD95. 


\section{Statistical analysis:}

Results were presented as mean \pm standard deviation (SD).Student $t$ test was used and linear-regression analysis was used to calculate correlation coefficient.

\section{Results:}

The mean \pm SD SLEDAI in patients was $14.25 \pm 6.76$. Ten patients

( $33.3 \%$ ) had mild activity with mean \pm SD SLEDAI $6.4 \pm 2$, eleven patients $(36.7 \%)$ had moderate activity with mean \pm SD SLEDAI $16 \pm 2.7$ and 9 patients $(30 \%)$ had severe activity with mean \pm SD SLEDAI $23 \pm 2$.

The anti-dsDNA antibodies were positive in all patients with mean \pm SD $264.36 \pm 114.85 \mathrm{IU} / \mathrm{ml}$. All control subjects were negative for anti-ds-DNA antibodies.

Serum level of IL-18 showed significant increase in SLE patients as compared to the control group $($ Mean \pm SD $246.13 \pm 114.32$ vs. Mean \pm SD,45.5 $\quad \pm 7.32 \quad \mathrm{IU} / \mathrm{ml} ; \quad \mathrm{p}<0.001$ )(table1).

The results of serum soluble CD95 showed significant elevation in all patients as compared to the control group(Mean \pm SD $648 \pm 116.96$ vs. $270.5 \pm 50.24 \mathrm{pg} / \mathrm{ml} ; \mathrm{p}<0.001)$ (table1). Serum sCD95 showed significant elevation in patients with moderate activity as compared to those with mild activity (Mean \pm SD $629.16 \pm 72.54$ vs. mean \pm SD $535 \pm 35.97 \mathrm{pg} / \mathrm{ml} ; \mathrm{p}<0.05$ ). Also, there was a significant increase in sCD95 in patients with severe activity as compared to those with moderate activity (mean \pm SD797.5 \pm 41.66 vs. mean $\pm \mathrm{SD} 629.16 \pm 72.54 \mathrm{pg} / \mathrm{ml} ; \mathrm{p}$ $<0.001$ ) (table 2).

The anti-dsDNA showed a significant positive correlation with the SLEDAI $(r=0.772 ; \mathrm{p}<0.01)$ (table 3 \& figure1).
There was a significant positive correlation between IL-18 and the SLEDAI $(r=0.670 ; p<0.01)($ table $3 \&$ figure 2).

There was a significant positive correlation between soluble CD95 and SLEDAI in patients $(\mathrm{r}=0.865$; $\mathrm{p}<0.01)($ table3 \&figure 3). Soluble CD95 in patients also showed significant positive correlation with anti-dsDNA antibodies ( $\mathrm{r}=0.775 ; \mathrm{p}$ $<0.01$ ) (table $3 \&$ figure 4)and with IL$18(\mathrm{r}=0.722 ; \mathrm{p}<0.01)($ table $3 \&$ figure 5$)$.

\section{Discussion:}

Systemic lupus erythematosus is a systemic autoimmune disease charact erized by B cell hyperactivity and defective T cell functions (14) .

A common feature of SLE is the breakdown of tolerance of self antigens, a consequence of which is the production of autoantibodies reactive to multiple self proteins (15).

Double-stranded DNA is a wellknown target of auto antibodies and is the hallmark for the diagnosis of SLE(16). Another feature of SLE is imbalance of $\mathrm{T}$ helper cell (Th) cytokines with production of excess proinflammatory cytokines as IL-18, IL-17 and IL-12 (17).

In this study there was a significant elevation of IL-18 in SLE patients as compared to the control group $(\mathrm{p}<0.001)$. These results are in agreement with those obtained by Esfandiari et al.,2001 (18)who found significant elevation of IL-18 in a group of SLE patients and reported that IL-18 accelerated the spontaneous autoim mune response through promotion of proliferation and interferon $\gamma$ production by Th1, CD8+ T cells and natural killer cells.

CD95(Apo-1/Fas) is a transme mbrane molecule. Fas -mediated 
apoptosis plays important role in the regulation of immune response to foreign antigens (19).

In the presesnt study there was a significant rise of $\mathrm{sCD} 95$ in all patients as compared to the control group $(\mathrm{p}<0.001)$. These results are in accordance to the results of Al-Maini et al., 2000 (20).

Also, our results showed a significant rise of soluble CD95 in SLE patients with moderate activity as compared to those with mild activity $(\mathrm{p}<0.05)$, and in patients with severe activity as compared to those with moderate activity $(\mathrm{p}<0.001)$. These results are in agreement with those obtained by Van der Linden et al., in 2001(21), who found significant elevation in soluble CD 95 in patients with severe SLE as compared to those with non severe SLE.

In our study, anti-dsDNA in all SLE patients was correlated with SLEDAI $(p<0.01)$. These results are in agreement with those obtained by Tyrrell-Price et al., 2001(22), who found that the anti-dsDNA antibodies mirror the disease activity activity in a group of SLE patients.

There was a significant positive correlation between IL-18 and SLEDAI $(p<0.01)$. These results are parallel to those obtained by Wong et al., 2000(23).

Data concerning defects in apoptosis in SLE were conflicting as some studies found no correlation between sCD95 and SLEDAI (24), others found significant positive correlation between SCD95 and SLDAI (25).
Our study showed a significant positive correlation between sCD95 and SLEADI $(p<0.01)$. We also found a significant positive correlation between s CD95 and anti-dsDNA antibodies $(\mathrm{p}<0.01)$. These results are in agreement with those obtained by Courtney et al., 1999(26) who found a significant positive correlation between sCD95 and anti-dsDNA antibodies. Mahran et al., 1999 found in a group of SLE patients a significant elevation of anti-dsDNA antibodies which was correlated with lymphocytes CD95. They said that increased lymphocyte apoptosis might provided more nuclear antigens for formation of immune complex resulting in increased disease activity (27). Other studies found that the high level of s CD95 in SLE patients might lead to decreased rate of Fas mediated apoptosis of lymphocytes in vitro and promote lymphocyte hyper activity which give rise to excessive auto antibodies causing the charect eristic features of the disease ( $28 \& 29)$.

Also, our results showed a significant positive positive correlation between SCD95 and IL-18, which is a marker of disease activity $(\mathrm{p}<0.01)$. IL18 can induce the Fas-fas ligand caspase- mediated apoptosis (30).

Conclusion: Soluble CD95 is increased in systemic lupus erythem atosus and is correlated with the disease activity index and with other activity markers as anti-dsDNA and IL18 ,so it can be used for monitoring the disease activity for proper management of SLE patients. 
Table(1):Mean \pm SD of IL-18 (IU/ml) and sCD95 (pg/ml) in patients as compared to the control group.

\begin{tabular}{|c|c|c|c|c|}
\hline & $\begin{array}{c}\text { Control } \\
(\mathrm{n}=10)\end{array}$ & $\begin{array}{c}\text { Patients } \\
(\mathrm{n}=30)\end{array}$ & $t$ & $\mathrm{P}$ \\
\hline -IL-18 (IU/ml) & $45.5 \pm 7.32$ & $246.13 \pm 114.32$ & 4.649 & $<0.001$ \\
$-\mathrm{SCD} 95(\mathrm{pg} / \mathrm{ml})$ & $270.5 \pm 50.24$ & $648 \pm 116 . .96$ & 12.83 & $<0.001$ \\
\hline
\end{tabular}

$\mathrm{P}<0.001=$ significant.

Table (2):Comparison of sCD95 level(pg/ml) in SLE patients with mild, moderate and severe activity.

\begin{tabular}{|c|c|c|c|}
\hline & $\begin{array}{c}\text { Mild activity } \\
(\mathrm{n}=10)\end{array}$ & $\begin{array}{c}\text { Moderate activity } \\
(\mathrm{n}=12)\end{array}$ & $\begin{array}{c}\text { Severe activity } \\
(\mathrm{n}=8)\end{array}$ \\
\hline -SLEDAI & & & $23 \pm 2$ \\
Mean+SD & $6.4 \pm 2$ & $16 \pm 2.7$ & 797.5 \\
-sCD95: & 535 & 629.16 & 41.66 \\
Mean & 35.97 & 72.54 & 8.32 \\
SD & & 3.09 & $\mathrm{p}<0.001$ \\
t & & $<0.05$ & \\
p & & & \\
\hline
\end{tabular}

$\mathrm{P}<0.05=$ significant.

Table (3):Correlations between SLEDAI and anti-dsDNA Abs and L-18 and Correlation between sCD95 and SLEDAI,anti- dsDNA and IL-18.

\begin{tabular}{|c|c|c|}
\hline Item & $r$ & $\mathrm{p}$ \\
\hline -Anti-dsDNA Abs/SLEDAI & 0.772 & $<0.01$ \\
-IL-18 / SLEDAI & 0.670 & $<0.01$ \\
-sCD95 / SLEDAI & 0.865 & $<0.01$ \\
-sCD95 /anti-dsDNA Abs & 0.775 & $<0.01$ \\
-sCD95 / IL-18 & 0.722 & $<0.01$ \\
\hline
\end{tabular}

$\mathrm{P}<0.01=$ significant . 
Magda I. M. El-Mahdy; $\boldsymbol{e t}$ al .

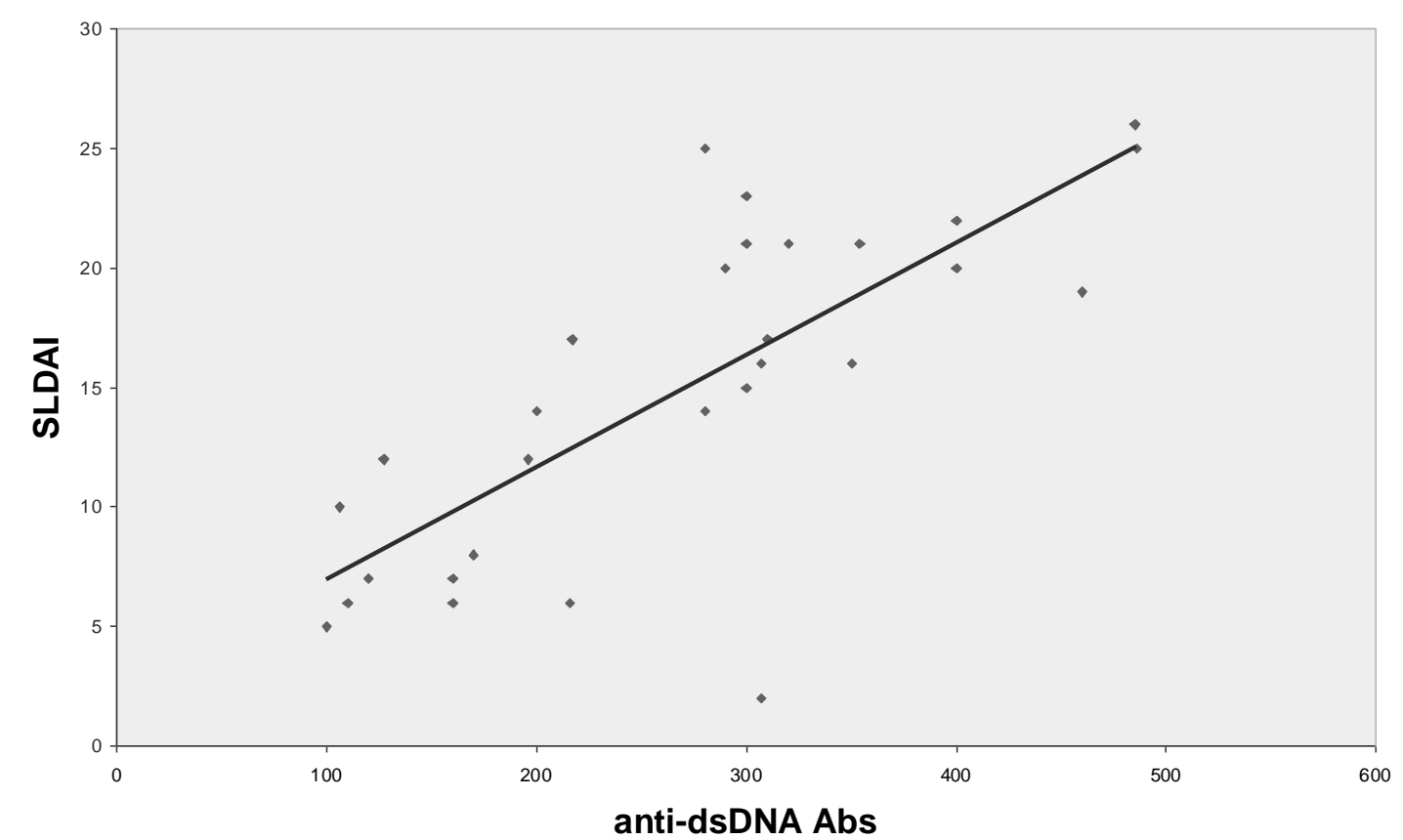

Figure 1: correlation between anti-dsDNA(IU/ml) antibodies and SLEDAI $(r=0.772 ; \mathrm{p}<0.01)$.

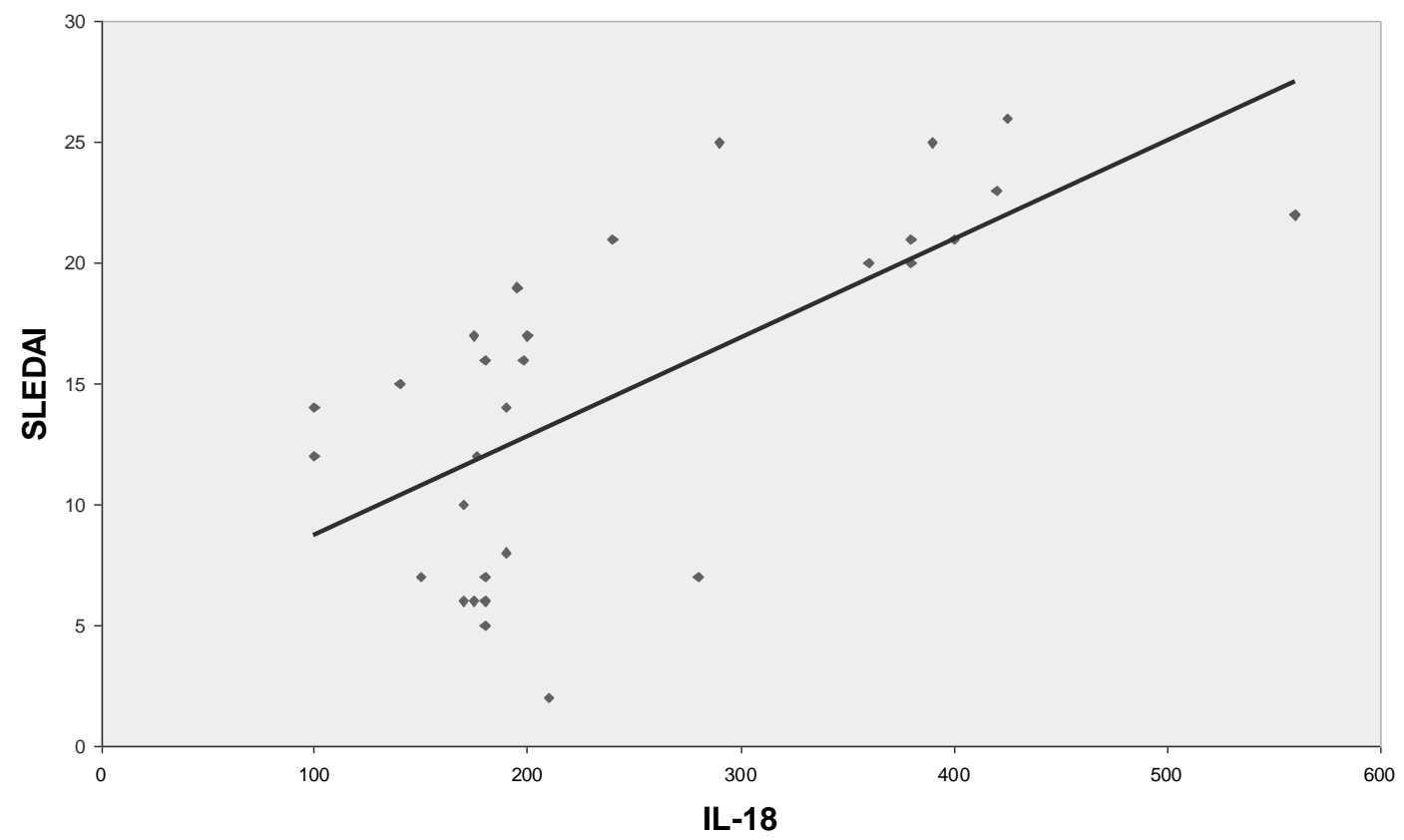

Figure 2: Correlation between IL-18 (IU/ml) and SLDAI $(\mathrm{r}=0.670 ; \mathrm{p}<0.01)$. 


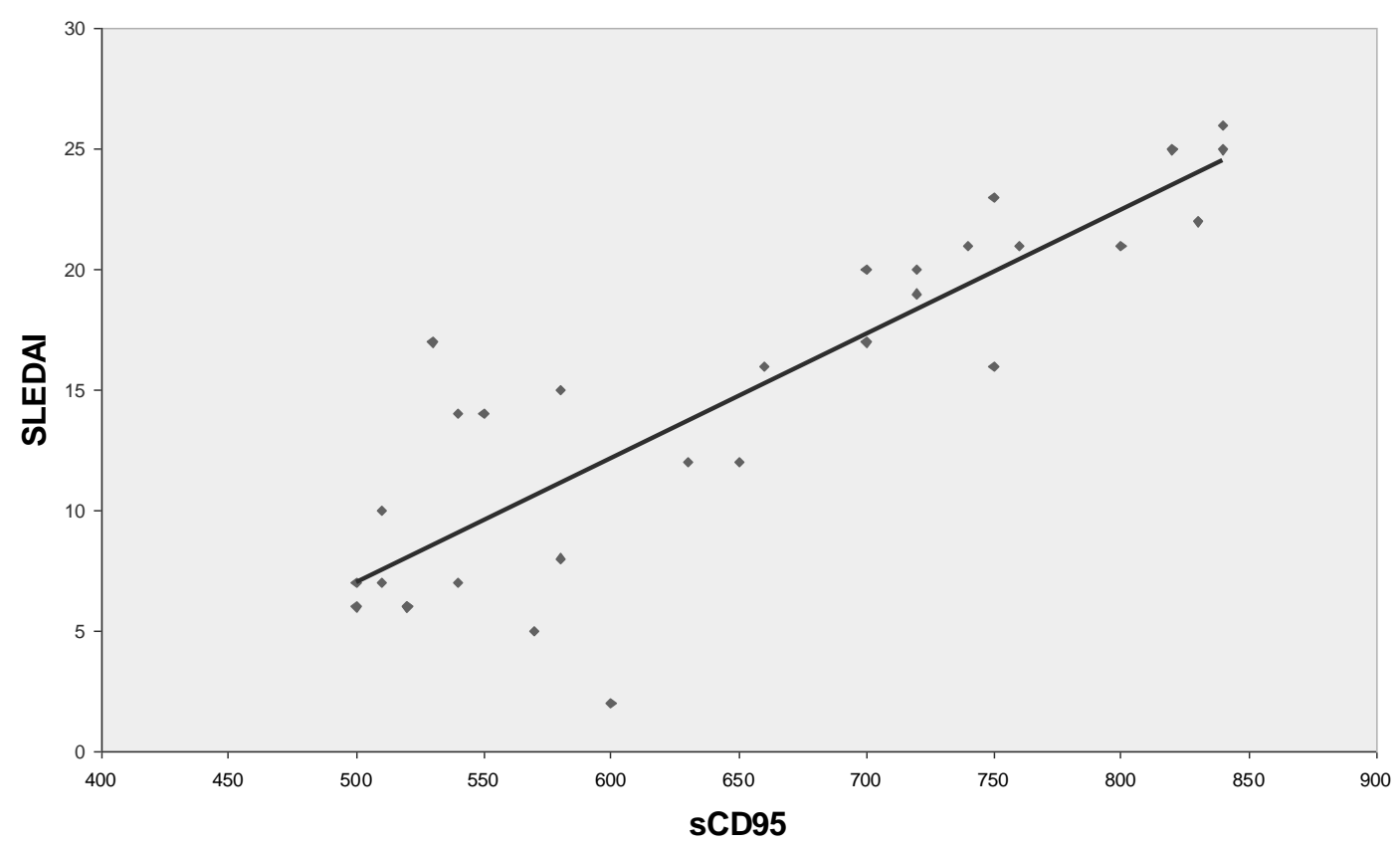

Figure 3: Correlation between s CD95 (pg/ml)and SLDAI $(\mathrm{r}=0.865 ; \mathrm{p}<0.01)$.

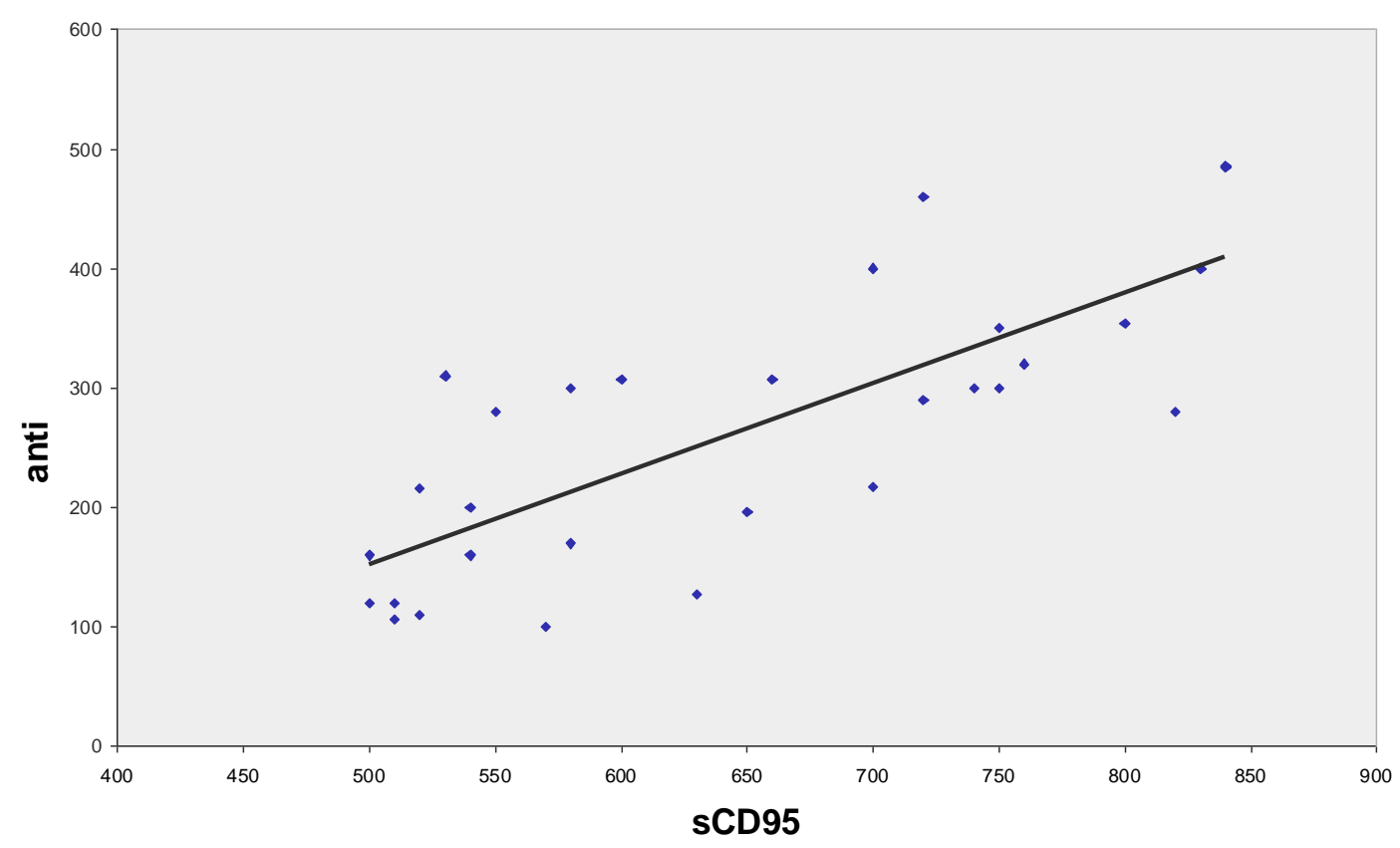

Figure 4: Correlation between $\mathrm{sCD} 95(\mathrm{pg} / \mathrm{ml})$ and anti-dsDNA antibodies (IU/ml). (r= $0.775 ; \mathrm{p}<0.01)$. 


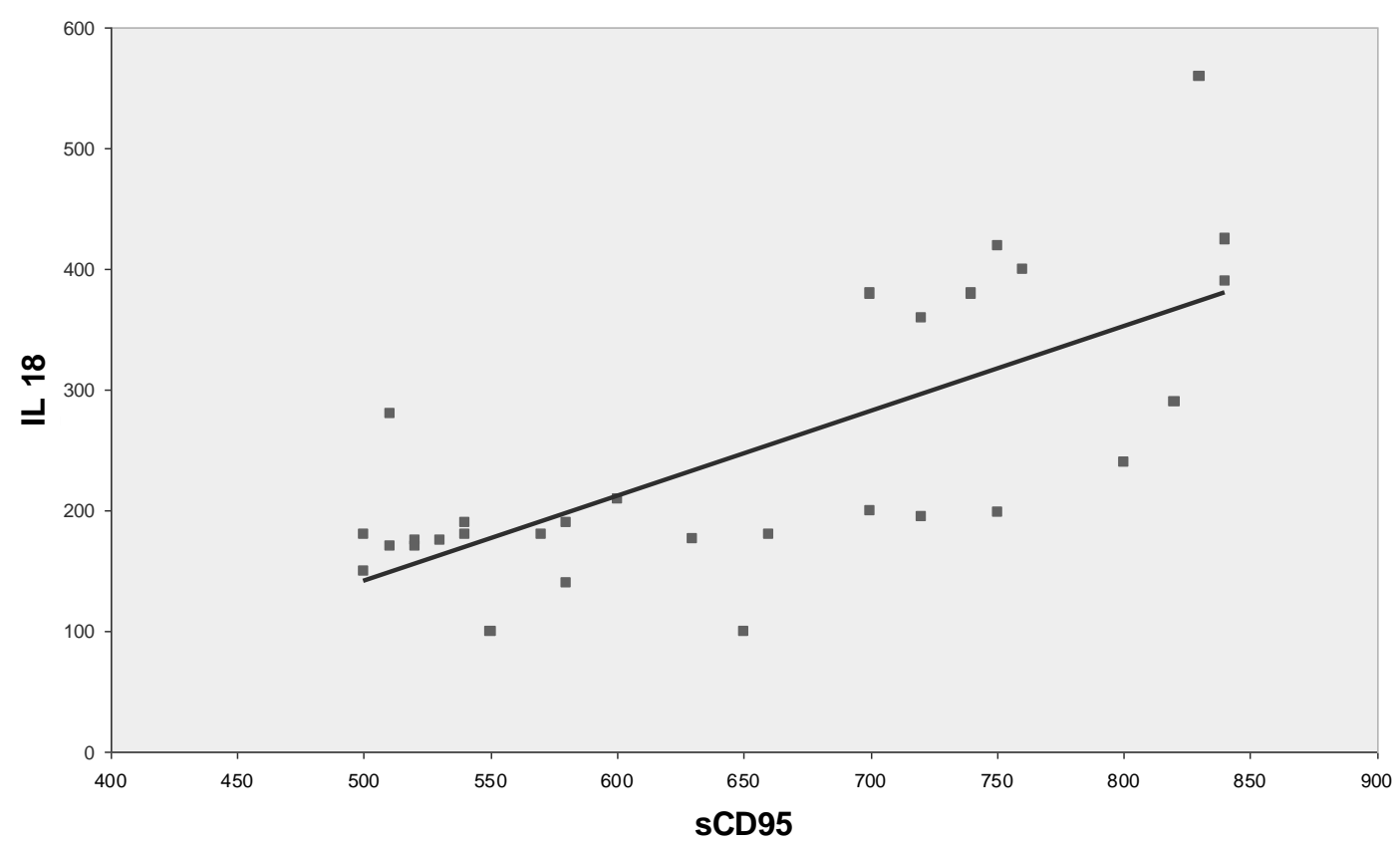

Figure 5: Correlation between sCD95 (pg/ml) and IL-18 (IU/ml) $(r=0.722 ; p<0.01)$.

\section{References:}

1. Cheng j. ,Zhou T. , Liu C. , Shapiro J.P., Brauer M.J. and Kiefer M.C. (1994):Protection from Fasmediated apoptosis by a soluble form of the soluble Fas molecule Science ; 263:1759-1762.

2. Leithauser F., Dhein J., and Mechtersheimer G. (1993) : Constitutive and induced expression of Apo-1, a new member of the nerve growth factor/tumor necrosis receptor superfamily, in normal and neoplastic cells. Lab .Invest.; 69: 415-429.

3. Digel W., Porzsolt F., Schmid M., Herrmann F. and Lesslaur W. (1992):High levels of circulating soluble receptors for tumor necrosis factor in hairy cell leukaemia and type B chronic lymphocytic leukaemia J. Clin.Invest.;89:16901693.

4. Vaishnaw A.K.,Orlinick

J.R.,Krammer P.H. and Chao M.V.(1999): The molecular basis for apoptotic defects in patients with CD95 (Fas/Apo-1) mutations. J.Clin.Invest.;103:355-363.

5. Salvesen G.S., ND Dixit M.V. (1997): Caspases: intacellular signaling by proteolysis Cell; 14:443-446.

6. Cascino I., Fiucci G., Papoff G., and Rubeerti G.(1995): Three functional soluble forms of human apoptosis-inducing Fas molecule are produced by alternative spl icing. J.Immunol.; 154:2706-2713.

7. $\mathrm{Yu}$ Y.,Hagihara M.,Ando K.,Gamsuvd B. and Matsuzawa H. (2001): Enhancement of human 
cord blood CD34+ cell-derived NK cell cytotoxicity by dendritic cells. J.Immunol.;166:1590-1600.

8. Stoll S.H.,Tsutsi M.,Yutsudo A.,Hakura T. and Tanimoto K.(1998):Productionof functional IL-18 by different types of murine and human dendritic cells (DC): Dc -derived IL-18 enhances Il12-dependent Th1 development. Eur.J.Immunol.; 28 :3231-3242.

9. Kotzin B. (1996): Systemic lupus erythematosus. Cell ; 85: 303-310.

10. Bijl M., Horst G., Limburg P.C. , Kallenberg C.G. (2001):AntiCD3-induced and anti-Fasinduced apoptosis in systemic lupus erythematosus (SLE). Clin.exp.Immunol.; 123:127-132.

11. Tan E.M.,Cohen A.S.,Fries J.F. Masi A.T. McShane D.J. and Rothfield N.F. (1982):The 1982 revised criteria for the classification of systemic lupus erythematosus. Artheritis Rheum.25:1271-1277.

12. Bombardier C., Gladman D.D.,Urowitz M.B., Caron D. and Chang C.C. (1992): Derivation of the SLDAI. A disease activity idex for lupus patients. Artheritis Rheum.; 35: 630-640.

13. Kammer G.M., Khan I.U. and Malemud C.J. (1994): Deficient type I protein kinase A isozyme activity in systemic lupus erythematosus $\mathrm{T}$ lymphocytes. J.Clin.Invest.;94:422-430.

14. Scheinecker C., Zwolfer B., Koller M., Manner G. and Smolen J.S. (2001): Alterations of dendritic cells in systemic lupus erythematosus: phenotypic and functional deficiencies. Artheritis Rheum.;44:856-865.15Eguchi K.(2001): Apoptosis in autoimmune diseases. Intern. Med.;40: 275-284.
15. Bruns A., Blass S., Hausdorf G., and Hiep F . (2000): Nucleasomes are major $\mathrm{T}$ and $\mathrm{B}$ cell autoanyigens in systemic lupus erythematosus. Artheritis Rheum.;43: 2307-2315.

16. Wong C.K., Ho C.Y. and $\mathrm{Li}$ E.K.(2000): Elevation of proinfla -mmatory cytokine (IL-18,IL17,IL-12) and Th2 cytokine (IL-4) concentr -ateions in patients with systemic lupus erythematosus. Lupus; 9:589-593.

17. Esfandiari E.,McInnes I.B., Lindop G., Huang F., Field M. and KomaipKoma M (2001) : A proinflammatory role of IL-18 in the development of spontaneous autoimmune disease. J.Immunol.;167: 5338-5347.

18. Watanabe-Fukunaga R.,Brannan C.I., Copeland N.G. and Nagata S.(1992):Lymphoproliferation isorder in mice explained by defects in Fas antigen that mediates apoptosis. Nature; 356:314-321.

19. Al-Maini MH.,Mountz J.D.,AlMohri H.A.,El-Ageb E.M., AlRiyami B.M. and Sevnson K.L.(2000):

20. Serum levels of soluble Fas correlate with indices of organ damage in systemic lupus erythmatosus. Lupus; 9:132-139.

21. 21- van der Linden M.W. van Lopik T., Aarden L.A., Westendorp R.G.J. and Huizinga T.W.J. (2001): Soluble CD95 concentrations are increased in patients with severe systemic lupus erythem atosus, but not in their first degree relatives .Ann. Rheum. Dis.;60: 237-241.

22. Tyrrell-Price J, Lydyard P.M. and Isenberg D.A. (2001):The effect 
of interleukin-10 and interleukin12 on the in vitro production of anti-doublestranded DNA antibodies from patients with systemic lupus erythematosus.Clin.Exp.Immuono $1 . ; 124: 118-125$.

23. Wong C.K., Ho C.Y., Li E.K. and Lam C.W.(2000):Elevation of plasma interleukin -18 , concent rations is correlated with disease activity in systemic lupus erythematosus. Rheumatology, 39: 1078-1081.

24. Rose L.M., Latchman D.S. Isenberg D.A. (1997):Elevated soluble Fas production in SLE correlates with HLA status not with disease activity. Lupus; 9: 717-722.

25. Bijl M., van Lopik T, Limburg P.C. and Spronk P.E. (1998):Do elevated levels of serum-soluble Fas contribute to the persistence of activated lymphocytes in systemic lupus erythematosus? J.Autoimmun.;11:457-463.

26. Courtney P.A., Crokard A.D., Williamson K., McConnell J.(1999):Lymphocyte apoptosis in systemic lupus erythematosus: relationships with Fas expression,serum soluble Fas and disease activity.Lupus; 8: 508517.

27. Mahran Z.M.,El-Fedawy S.F.,Fahmy H.M. and Tamara F.(1999): Apoptosis in peripheral lymphocytes in systemic lupus erythematosus. Ain Shams Medical Journal;50:669-676.

28. Van Lopik T.,Bijl M.,Hart M.,Boeije L., Gesner T. and Creasy A.A (1999): Patients with systemic lupus erythematosus with high plasma levels of sFAS risk relapse. J.Rheumatol.; 26:60-67.

29. Miret C., Font J., Garcia-Carrasco M. Fileea $X$. and Cervera R. (2001): Relationship of oncogenes (sFas, Bcl-2) and cytokines (IL-10, alfa- TNF) with the activity of systemic lupus erythmatosus. Anticancer Res.; 21:3053-3059.

30. Tsutsui H.,Matsui K.,Okamura H. and Nakanishi K. (200): Pathophysiological roles of interleukin-18 in inflammatory liver disease. Immunol . Rev.; 174 :192-209. 


\title{
مستويات سى دى 95 الذائب فى المصل فى مرضى الأببة الحمراء
}

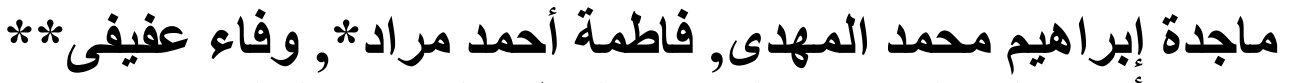

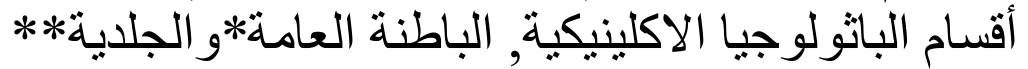 \\ كلية الطب ـ بنات. جامعة الاز هر لإطنة العامه
}

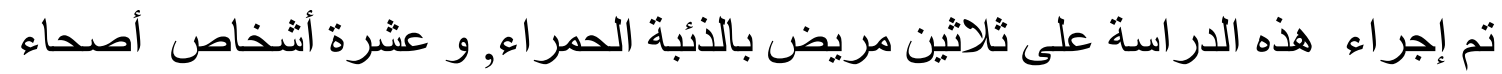

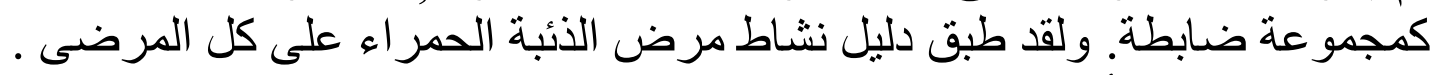

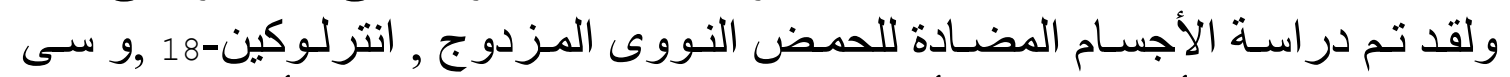

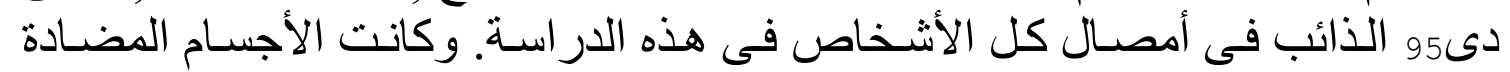

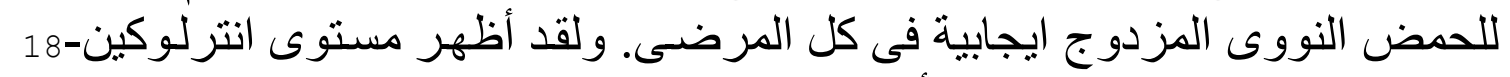

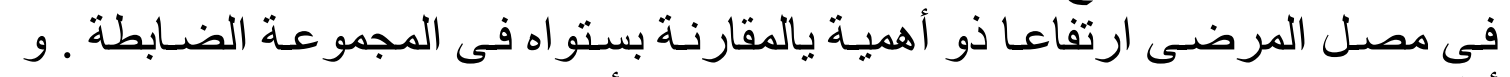

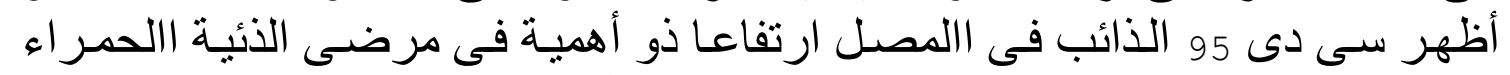

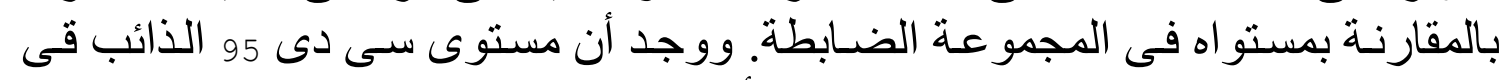

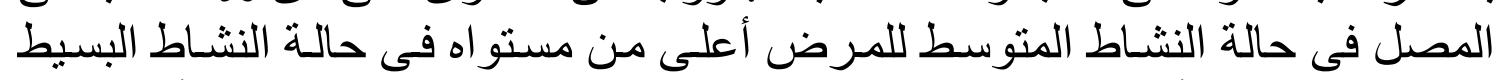

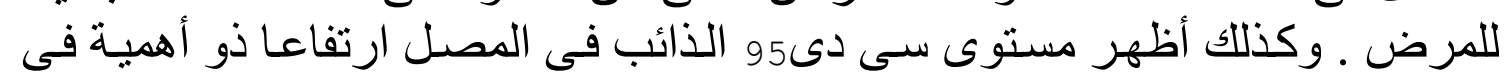

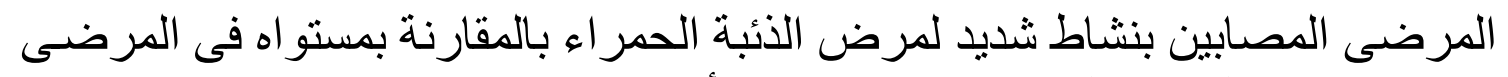

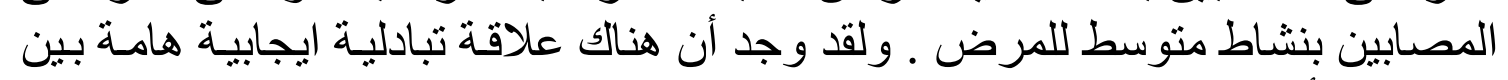

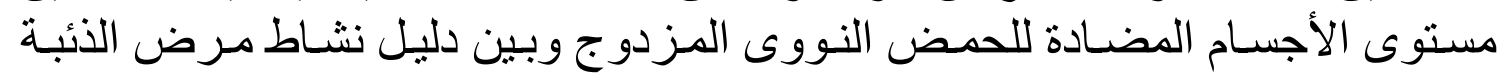

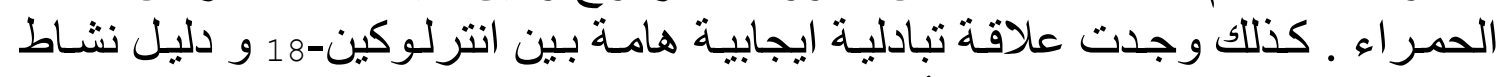

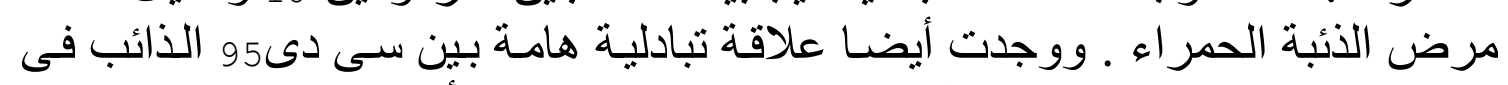

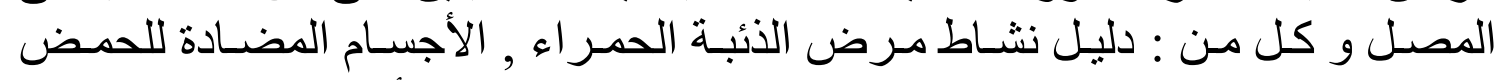

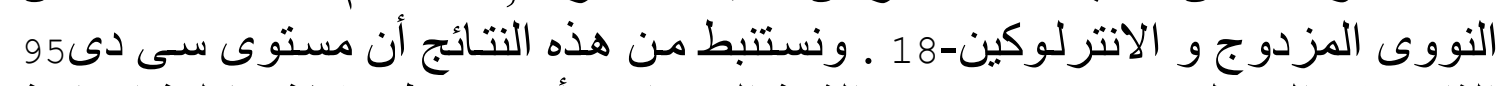

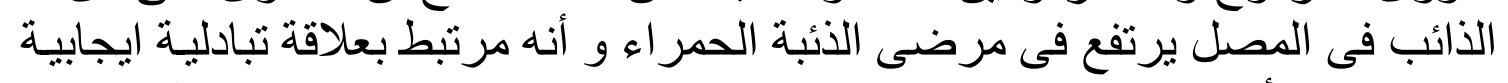

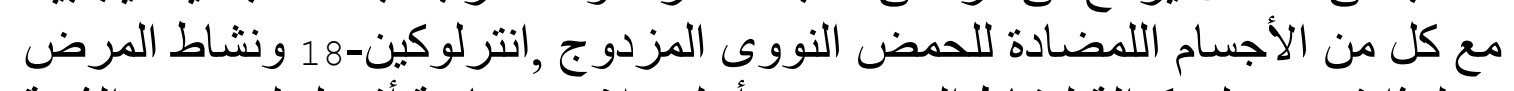

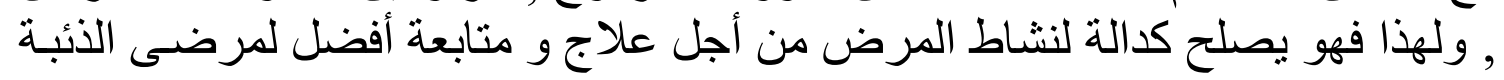
الحمر اء. . 